\title{
Dynamics of Value Chain Governance: Increasing Supplier Competence and Changing Power Relations in the Periphery of Automotive Production-Evidence from Bursa, Turkey
}

\section{Güldem Özatağan}

To cite this article: Güldem Özatağan (2011) Dynamics of Value Chain Governance: Increasing Supplier Competence and Changing Power Relations in the Periphery of Automotive Production-Evidence from Bursa, Turkey, European Planning Studies, 19:1, 77-95, DOI: 10.1080/09654313.2011.530393

To link to this article: http://dx.doi.org/10.1080/09654313.2011.530393

\section{Published online: 14 Dec 2010.}

Submit your article to this journal 5

Џll Article views: 331

Q View related articles $\asymp$

Citing articles: 4 View citing articles 지 


\title{
Dynamics of Value Chain Governance: Increasing Supplier Competence and Changing Power Relations in the Periphery of Automotive Production- Evidence from Bursa, Turkey
}

\author{
GÜLDEM ÖZATAĞAN
}

Department of City and Regional Planning, Faculty of Architecture, Izmir Institute of Technology, Gülbahçe Köyü, Urla, Izmir, Turkey

(Received May 2009; accepted December 2009)

\begin{abstract}
Adopting a global value chain $(G V C)$ approach, this paper focuses on the ways in which global automotive transnational corporations coordinate their value chains with suppliers in the periphery of automotive production. In particular, it directs attention to particular forms of chain relations established by lead firms with suppliers in Turkey and the ways in which these chains are coordinated. Findings indicate that as component suppliers in the periphery of automotive production, such as those in Bursa, have gained the competencies not only to manufacture to the cost, quality and flexibility specifications required by their customers but also of design and product development, lead firms in the automotive industry have turned to modular value chains, where competent suppliers provide a range of services with less dependence on their customers, as a way of sourcing from these suppliers. I use this evidence to argue that GVC governance is dynamic and suppliers in the periphery have some room for breaking power asymmetries associated with specific modes of governance in GVCs.
\end{abstract}

\section{Introduction}

In recent decades, the automotive industry has experienced a significant restructuring. The strategies of its lead firms have become increasingly internationalized in a way to expand across national borders, and peripheral locations have become core actors of their new strategies. This process has taken place in the form of a new division of labour in which transnational corporations (TNCs) have been the key actors in the governance of

Correspondence Address: Güldem Özatağan, Department of City and Regional Planning, Faculty of Architecture, Izmir Institute of Technology, Gülbahçe Köyü, Urla, Izmir, Turkey. Email: guldemozatagan@iyte.edu.tr 
spatially dispersed value chains of automotive manufacturers in advanced countries with supplier firms typically located in developing countries (Gereffi, 2001; Humphrey, 2003b; Humphrey \& Memedovic, 2003; Sturgeon \& Lester, 2004).

Over the last few decades, a fruitful approach, the global value chain (GVC) perspective, has emerged which focused on the ways in which global automotive TNCs coordinate their value chains. The GVC perspective advocated the idea that they are taking control over the key high value-added activities (Gereffi, 2001) and attempted to enhance our knowledge on the nature of this control by directing attention to asymmetrical power relationships between TNCs and their suppliers (Barnes \& Kaplinsky, 2000; Layan, 2000; Humphrey, 2003b; Humphrey \& Memedovic, 2003; Barnes et al., 2004; Posthuma, 2005). On the ways in which TNC chains are coordinated in the automotive industry, Sturgeon (2003) observes that there is a move towards modular chains, but the subject has not received sufficient attention with regard to supply chain dynamics with suppliers in the periphery of automotive production, especially when compared with the recent attention given to the supply chain dynamics between assemblers and their direct suppliers and the changing inter-firm relations between them (Sturgeon \& Florida, 2000; Dicken, 2003; Sturgeon \& Lester, 2004; MacDuffie \& Helper, 2005). In this article, I consider the extent to which the Turkish automotive components industry-integrated in the automotive value chains of European and global TNCs after the 1990s-provides evidence concerning the ways in which automotive TNCs coordinate their value chains with suppliers in the periphery of automotive production. The findings indicate that they have made extensive use of modular value chains, where competent suppliers provide a range of services with less dependence on their customers, as a way of sourcing components from suppliers in Bursa-a major automotive components production node in Turkey.

This last point is important because the move of design responsibility to global first-tier suppliers in the automotive industry has been fuelling an expectation that they have gained an independent stance vis-à-vis their customers (Sturgeon, 2002) and that inter-firm relations between assemblers and suppliers in the automotive industry have become more collaborative and longer term (Sadler, 1998; Follis et al., 2002; MacDuffie \& Helper, 2005). However, still such less asymmetrical relations are expected to be less likely to develop with peripheral suppliers since they do not have the competencies required for such relations to develop (Humphrey \& Schmitz, 2002b; Sturgeon \& Lester, 2004). It is maintained that they are confined to lower tiers of components manufacturing where competencies are limited to meeting cost, flexibility and quality requirements of their customers (Humphrey, 2003b; Humphrey \& Memedovic, 2003) and that it is becoming increasingly difficult for them to upgrade their capabilities since the rise of global lead firms presents new challenges to suppliers in developing countries (Sturgeon $\&$ Lester, 2004). Here I revisit this expectation and report that the organizational restructuring of the automotive components industry has offered potentials to manufacturers in the periphery of automotive production. More specifically, I show that as components suppliers in the periphery of automotive production, like those in Turkey, have gained the competencies not only to manufacture high-quality components with the required flexibility and at high speeds but also of design and product development, European and global lead firms willing to relinquish the design and product development functions to optimize their learning processes, minimize costs and share the risks have turned to modular value chains in sourcing from these suppliers. This implies that value chain relations of global TNCs with their suppliers in Bursa have become less asymmetrical 
and that Turkish suppliers now provide a range of services with less dependence on their customers.

I use this evidence to provide further support to the theoretical position elaborated by Dicken et al. (2001), Humphrey and Schmitz (2002a), Smith (2003) and Tokatl1 (2007) that GVC governance is dynamic and suppliers in the periphery of automotive production have some room to overcome barriers associated with a specific type of chain and to increase the skill content of their competencies. I do so by assessing the ways in which the relationships between suppliers and their lead firms are coordinated in the automotive value chain in Bursa by building on the GVC typology suggested by Gereffi et al. (2005) and using a questionnaire survey of 103 component suppliers.

The rest of the paper is organized as follows. The following section provides an overview of the organizational restructuring that the supply industry has experienced since the 1990s and discusses its implications for GVC governance in the automotive industry. In Section 3, I specify the research question and provide an explanation of the methodology and the data used to answer these questions. In Section 4, the core of the paper, I build on the GVC governance types suggested by Gereffi et al. (2005) to anticipate change in the automotive value chain in Bursa. Here I first present background information on the integration of Bursa into the European and global automotive production system. Then I provide a systematic understanding of the ways in which the relationships between suppliers and their lead firms are coordinated based on survey data and use this evidence to discuss how governance structures in the automotive value chain of Bursa have evolved. Finally, in Section 5, I reflect on the dynamic nature of GVC governance and discuss its policy implications.

\section{Organizational Restructuring, GVC Governance and the Reconfiguration of Power in the Components Industry}

The automotive industry is an example of a producer-driven chain where global leaders are TNCs or other large integrated enterprises. They organize their chains by outsourcing production and play a central role in controlling globally dispersed value chains (Gereffi, 2001; Humphrey, 2003b; Humphrey \& Memedovic, 2003; Sturgeon \& Lester, 2004). Since the mid-1980s, the automotive industry has experienced a process of significant restructuring. In pursuit of increasing profits and sustaining competitiveness, lead firms have decreased the degree of their vertical integration, identifying and focusing on core competencies - especially on product innovation, marketing and other activities related to brand development - and moving upstream along the value chain, while selling off and transferring responsibility of a large range of non-core activities to specialized suppliers. This has included a process of spin-offs of the in-house components production activities of the major assemblers, which have been given separate identities for doing business not only for their parent companies but also for other assemblers (Humphrey \& Memedovic, 2003).

This organizational change has occurred at the same time that lead firms have introduced significant changes in their sourcing strategies. This has included a change in the nature of components supply characterized by a shift from the supply of single components towards the supply of complete modules and systems. ${ }^{1}$ Lead firms have come to expect their direct suppliers to provide them with a number of related modules, ready to be assembled in the production line. The key idea is to make it easier to change and 
improve components (Camuffo, 2002) and to outsource and/or relocate module design and production in a more feasible way (Sturgeon \& Lester, 2004). This is believed to reduce asset specificity since the customer can buy the module from any supplier as long as the module fulfils its predefined function and its compatibility is assured by the standardized interface. ${ }^{2}$

As a subsequent impact of the processes of vertical disintegration and the move towards modular supply, lead firms have gone through a process of reduction and systematization of their suppliers. They have decreased the number of their first-tier suppliers, deliberately preferring those capable of designing complex modules and systems on the basis of the assemblers' specific requirements using their own technologies and of supplying them in globally dispersed geographies; enabling the assemblers to transfer product development and to design risks and costs to component suppliers, while taking advantage of their specialized technological skills and competencies (Humphrey, 2003b).

One of the most notable features of this organizational change has been the rise of global suppliers, which have increased their technological competence and expanded their global reach through the acquisition of competitors from across the world (Humphrey, 2000; Sturgeon, 2002, 2003; Humphrey \& Memedovic, 2003; MacDuffie \& Helper, 2005). These have become the preferred suppliers of lead firms and have been given greater responsibility for component and module design and product development. A subsequent impact of this re-organization has been the organization of the supply chain in tiers in the context of a division of labour. Humphrey and Memedovic (2003) state that the requirements of each tier are distinct: while assemblers and their global ( 0.5 tier) suppliers need global reach, innovation, design and product development capabilities and considerable financial resources, the first-tier suppliers require design, innovation and product development capabilities but their global reach may be more limited. Second-tier suppliers work to specifications of assemblers or their direct suppliers and require competencies to meet cost, flexibility and quality requirements. Finally, the competencies needed in the third tier are much limited and third-tier suppliers compete on the basis of cost.

The rise of global suppliers and the systematization of the supply industry in tiers imply that customer-supplier relations in the automotive industry are all about power. This is especially so with suppliers in the periphery of automotive production, for whom differences from the 0.5 and first-tier suppliers which are typically located in the core of automotive production have become even larger. Over the last few decades, a fruitful approach, the GVC perspective, has emerged which focused on the asymmetrical power relationships between lead firms and suppliers in producer-driven chains (Barnes \& Kaplinsky, 2000; Layan, 2000; Humphrey, 2003b; Humphrey \& Memedovic, 2003; Barnes et al., 2004; Posthuma, 2005). In this context, "value chain governance" is defined as a concept which reflects power asymmetries that arise due to the power of lead firms to coordinate what is to be produced, how it is to be produced and how much will be produced (Dolan \& Humphery, 2000; Humphrey \& Schmitz, 2000).

The GVC literature has identified four types of relations put in place to achieve coordination in GVCs, each associated with different power asymmetries. In market-based chains, the basis of customer-supplier relations is price information and specifications (Sturgeon, 2002; Gereffi et al., 2005). Suppliers produce a range of standard products that are available to a wide range of lead firms, and the selection of suppliers is based on price-based competition (Humphrey, 2003b). In captive chains, suppliers carry out specific tasks following detailed instructions provided by the lead firms, which are 
responsible for product design (Dicken, 2003; Humphrey, 2003a). This means ensuring that the same part is sourced from a number of different suppliers, which are awarded contracts on the basis of price. Hence, in captive chains, customer-supplier relations are asymmetrical. Suppliers are subordinated to powerful lead firms who specify product and process characteristics, leaving the former with little autonomy to develop relatively independent strategies (Humphrey \& Schmitz, 2000, 2002a, 2002b; Humphrey, 2003a; Schmitz, 2004). As explained by Humphrey and Schmitz (2002a), one major reason for lead firms to establish such asymmetrical power relationships is the risk of supplier failure: not sure about their competence, lead firms deliberately support their suppliers, facilitating the flow of knowledge and learning to take place. However, in providing this support, lead firms tend to retain the type of knowledge that is part of their competencies which most of the time include design, product development, marketing and branding the returns of which are much higher.

Before the 1980s, inter-firm relationships put in place to achieve coordination in the automotive value chain were characterized by captive or market-based relations. As production in the automotive industry has become more and more globally dispersed and suppliers have been increasingly given responsibility for design and product development, supply chains have required sophisticated forms of coordination, especially in relation to integrating components into the design of modules and systems and ensuring product quality. This has meant that coordinating supplier relationships on the basis of collaboration became a requirement (Sadler, 1998; Follis et al., 2002; MacDuffie \& Helper, 2005). This implies the rising importance of network-based value chains in the automotive industry, which are two types: relational and modular value chains. Relational chains are characterized by more even relationships and build on complementary competencies between the supplier and the customer. Relations are long term and collaborative, and complex information is exchanged between lead firms and their suppliers.

On the other hand, the logic of modular production and the subsequent shift in design responsibility to suppliers required GVC researchers to introduce the concept of modularity into value chain governance. This idea finds itself in the notion of modular value chains which provide looser, thinly relational interactions compared to relational chains (Sturgeon, 2002; Gereffi et al., 2005). This is achieved by extensive codification through the use of highly automated and standardized product and process technologies which enables the transfer of specifications between lead firms and their suppliers and hence reduces the asset specificity of the transaction. One other important aspect of modular chains is supplier competence required for making the products according to the lead firms' specifications and delivering them in a timely fashion and also for designing a solution, adapting a basic design to the customer's specific requirements or designing a module or subsystem using its own technology. Defined this way, in modular chains, competent suppliers have an independent stance vis-à-vis their customers which allow them to provide a range of services with less dependence on lead firms (Sturgeon, 2002, 2003).

Now that the coordination of automotive value chains has required more collaborative relations between lead firms and competent suppliers, a potentially favourable opportunity for a more balanced relationship between powerful lead firms and their relatively powerless components suppliers was noted (Sturgeon, 2002; Yusuf, 2004). However, it is maintained that such relations are built and maintained between assemblers and their direct suppliers typically located in the core of automotive manufacturing, while they are less likely to develop with suppliers in the periphery of automotive production since they do 
not have the competencies required for such relations to develop (Humphrey \& Schmitz, 2004; Sturgeon \& Lester, 2004). What is more, it is asserted, the rise of global lead firms presents new challenges to suppliers in developing countries: they are confined to lower tiers of components manufacturing where competencies are limited to meeting cost, flexibility and quality requirements (Humphrey, 2003b; Humphrey \& Memedovic, 2003) and it is becoming increasingly difficult for them to upgrade their capabilities (Sturgeon \& Lester, 2004). Supporting this assertion, Evren (2002, p. 299) shows that the Turkish car industry "... has been excluded from all the core activities such as design and product development..." and argues that the possibility for the development of "smart activities and innovation in less favoured regions" is unlikely "...unless parent firms change their production and local sourcing strategies". These assertions suggest that global lead firms marshal the power of others, especially those suppliers in developing countries from which they source.

Power relationships are indeed an important feature of value chains and are clearly unequal in the automotive industry. However, power relations are not static and understanding the dynamism of these power relations is important since it implies a change in modes of value chain coordination (Humphrey \& Schmitz, 2002a; Tokatli \& Kizılgün, 2004; Gereffi et al., 2005). As Dicken et al. (2001, p. 105) also recognized, value chains are constituted, transformed and reconstituted through asymmetrical and evolving power relations. This implies that the limits and barriers associated with specific modes of value chain coordination might be temporary (Humphrey \& Schmitz, 2002a). This may be basically due to two developments. First, existing producers may acquire new capabilities which may decrease the need for global lead firms to maintain control over the suppliers. As mentioned earlier, one major reason that lead firms establish asymmetric power relationships/tight coordination is the risk of supplier failure. As the competencies of suppliers increase, lead firms may be more likely to vacate certain spaces.

Second, lead firms governing a specific value chain may be willing to relinquish some functions into which producers might move (Humphrey \& Schmitz, 2002a). On this issue, recent evidence implies that since Humphrey and Memedovic (2003) described the division of labour in the automotive supply chain, manufacturers in the hierarchy of the supply chain have taken new roles. First of all, there has been increasing requests from the second-tier suppliers for design expertise. Herrigel (2004), for example, shows that first-tier suppliers, which are increasingly charged by vehicle assemblers with the responsibility for design and product development of increasingly complex modules and systems, have faced difficulties in mastering all the design, technology and manufacturing operations. By increasingly requiring their own suppliers to take on some design responsibilities - though retaining the overall control of the product development process - they have sought to optimize their learning processes, minimize costs and share the risks. Evidence on Fiat's Piedmontese auto-production system in Italy (cited in Whitford \& Enrietti, 2005, p. 785) reinforces Herrigel's findings. This evidence mentions increasing requests from the second-tier suppliers for design expertise and intensification of relationships between firstand second-tier suppliers. Secondly, there is evidence that the pressure on higher tier suppliers to innovate has moved down the automotive supply chain. Follis et al. (2002), for example, show that lower tier suppliers have experienced a strong push from their customers to innovate and a substantial majority deliver just-in-time to their clients. All these recent evidences imply that design and product development is less in the domain of direct suppliers to vehicle manufacturers and that the increasingly standard practices observed in 
the higher tiers of the supply chain are replicated at lower levels. This is an important development as it points to a shift in the distribution of power in the automotive supply chain and hence implies a change in value chain governance.

\section{Research Questions and Methodology}

All these arguments need empirical support. The following case study has such an aim. It specifically addresses the following questions:

- What are the ways in which lead firms in the automotive industry coordinate their networks with suppliers in Bursa, Turkey?

- How has GVC governance in the automotive industry of Bursa evolved since the 1990s?

- Has there been a shift in the distribution of power in the automotive value chain of Bursa?

I shall try to answer these questions by building on the typology of GVC governance suggested by Gereffi et al. (2005). They associated the types of value chain governance underlined above with combinations of three variables, namely, the complexity of interfirm transactions, the ability to codify transactions and the capabilities of suppliers (Gereffi et al., 2005). The combination of these three variables allows for the types of value chain governance to lie between two extremes ranging from non-explicit coordination and power symmetry towards high explicit coordination and power asymmetry (Table 1). I shall use this typology to provide a more systematic understanding of the ways in which lead firms coordinate the automotive value chain in Bursa and anticipate change in the automotive value chain governance in Bursa. ${ }^{3}$

This will be done based on survey data collected during December 2005-December 2006 using structured, face-to-face interviews with owners, managers, foreign trade managers or purchasing managers of 103 components suppliers in Bursa. The list of firms operating in the automotive components industry was provided by the Chamber of Industry and Commerce and by the Undersecretariat of the Prime Ministry for Foreign Trade for Bursa, Turkey (2005). The original database included information on names, locations, telephone numbers and addresses of 406 firms in Bursa. The sample was

Table 1. Types of GVC governance

\begin{tabular}{|c|c|c|c|c|}
\hline $\begin{array}{l}\text { Type of } \\
\text { governance }\end{array}$ & $\begin{array}{l}\text { Ability to codify } \\
\text { the transaction }\end{array}$ & $\begin{array}{l}\text { Complexity of the } \\
\text { transaction }\end{array}$ & $\begin{array}{l}\text { Supplier } \\
\text { capability }\end{array}$ & $\begin{array}{c}\text { Degree of explicit } \\
\text { coordination and power } \\
\text { asymmetry }\end{array}$ \\
\hline Market & High & Low & High & Low \\
\hline Modular & High & High & High & \\
\hline Relational & Low & High & High & \\
\hline Captive & High & High & Low & \\
\hline Hierarchy & Low & High & Low & \\
\hline Exclusion & High & Low & Low & \\
\hline Unlikely & Low & Low & High & \\
\hline Unlikely & Low & Low & Low & High \\
\hline
\end{tabular}

Source: Adapted from Gereffi et al. (2005). 
Table 2. Response rates, Bursa, Turkey

\begin{tabular}{|c|c|c|c|c|c|c|}
\hline & \multicolumn{6}{|c|}{ Bursa, Turkey } \\
\hline & \multicolumn{2}{|c|}{ Foreign } & \multicolumn{2}{|c|}{ Domestic } & \multicolumn{2}{|c|}{ Total } \\
\hline & $\begin{array}{l}\text { Number } \\
\text { of firms }\end{array}$ & $\begin{array}{l}\text { Response } \\
\text { rate }(\%)\end{array}$ & $\begin{array}{l}\text { Number } \\
\text { of firms }\end{array}$ & $\begin{array}{l}\text { Response } \\
\text { rate }(\%)\end{array}$ & $\begin{array}{l}\text { Number } \\
\text { of firms }\end{array}$ & $\begin{array}{c}\text { Response } \\
\text { rate }(\%)\end{array}$ \\
\hline $\begin{array}{l}\text { Firms } \\
\quad \text { interviewed }\end{array}$ & 18 & 56.25 & 85 & 25.30 & 103 & 27.99 \\
\hline $\begin{array}{l}\text { Total number of } \\
\text { accessible } \\
\text { firms }\end{array}$ & 32 & & 336 & & 368 & \\
\hline
\end{tabular}

Source: Survey data.

selected using stratified systematic sampling method on the basis of firm ownership. The firm list was divided into two depending on whether firms were locally or foreign owned. Accordingly, the sample consisted of 75 foreign and 63 locally owned firms. The sample frame is determined on the basis of $20 \%$ response rate. Of the firms approached, 8 foreign and 30 locally owned were inaccessible either because of wrong contact information or because the firm started to operate in another sector, making a total of 38 firms. Out of the 368 accessible firms, 103 of them provided consistent and usable information leading to a response rate of more than $25 \%$ (Table 2).

The survey was designed to get information in two key areas:

(a) "firm-specific": aimed at obtaining information on firms' general characteristics (employment, ownership and the type of product produced);

(b) "transaction-specific": aimed at providing information on firms' customers and the nature of the interaction with their most important/main customer (which has the highest share in the interviewed firm's total sales).

The first group of information provided an understanding of the general characteristics of surveyed firms (Table 3), while the second group was used to develop a typology of value chain governance in line with the one suggested by Gereffi et al. (2005). To do so, three dimensions of governance were identified. These three dimensions are:

(1) customer engagement in standardized transactions: this is identified on the basis of the question which asked the extent to which the firm's main customer:

(a) specifies product and process characteristics;

(b) imposes quality and technical standards;

(2) customer engagement in complex transactions: this is identified on the basis of the question which asked the extent to which the firm's main customer takes part in:

(a) product and process development;

(b) upgrading technology;

(c) training;

(3) supplier capability: this is identified on the basis of the question which asked the extent to which the firm is engaged in: 
Table 3. General characteristics of surveyed firms

\begin{tabular}{|c|c|c|}
\hline & Number & Percentage $(\%)$ \\
\hline \multicolumn{3}{|l|}{ Ownership } \\
\hline TNC subsidiary & 8 & 7.8 \\
\hline Domestic with equity links & 10 & 9.7 \\
\hline Domestic & 85 & 82.5 \\
\hline \multicolumn{3}{|l|}{ Size (employment) } \\
\hline $1-24$ & 30 & 29.1 \\
\hline $25-99$ & 33 & 32 \\
\hline $100-199$ & 22 & 21.4 \\
\hline 200 and more & 18 & 17.5 \\
\hline \multicolumn{3}{|l|}{ Type of product produced ${ }^{\mathrm{a}}$} \\
\hline Rubber and plastic parts & 14 & 16.3 \\
\hline Auto parts & 54 & 62.8 \\
\hline Metal parts & 18 & 20.9 \\
\hline
\end{tabular}

Total number of firms does not count to 103 since information for 11 firms is missing.

Source: Survey data.

(a) the definition of product characteristics:

- improving original designs and specifications;

- modifying and improving product features;

(b) research and development activities:

- developing new products;

- developing new production processes/methods;

- developing new designs.

In the survey, firms were expected to attribute a degree to each of the variables under each dimension ranging between "no engagement", "to some extent" and "to a large extent". Values of 1, 2 and 3 were given for the three degrees of engagement, respectively. The coefficient for each dimension was defined as the sum of the values attributed to each variable under the relevant dimension, divided by the maximum possible amount for each of the three dimensions ( 6 for the first, 9 for the second and 15 for the third dimension).

Cutting across these three dimensions, firms were classified on the basis of the value of the coefficients in each of the three dimensions as "high", "medium-high", "medium", "low" and "no". Then, in order to overcome the problem of insufficient frequencies and of complexity, the categories were reduced to two. In the final solution, firms with a coefficient between 1 and 0.67 are classified as "high" and those with a coefficient less than 0.67 are classified as "low". Firms were then classified on the basis of their "high" and "low" positions on each of the three dimensions, which were then combined to yield eight possible types of value chain governance, which reflect asymmetric power relations in value chains (Table 1$){ }^{4}$

This typology provided a systematic understanding of the ways in which the relationships between suppliers and their lead firms are coordinated and is used to anticipate the ways in which governance structures in the automotive value chain of Bursa have evolved. Investigation of the automotive value chain governance in Bursa on the basis of this typology revealed how the increased capabilities of Turkish suppliers not only to 
manufacture to the cost, quality, speed and flexibility specifications of lead firms but also of design and product development came together with the organizational changes in the automotive industry and turned lead firms to employ modular value chains in sourcing from these suppliers. I then used this evidence to highlight the dynamic nature of GVCs. Before going into the details of findings out of this investigation, the following part presents background information on Bursa and its integration into the European and global automotive system since the 1990s.

\section{Empirical Evidence: Bursa and its Integration into the European and Global Automotive System}

\subsection{Dynamics of Integration}

Bursa is a major automotive components producing node in Turkey. Its emergence as an automotive producing node dates back to late 1960s when the manufacturing plants of Fiat and Renault were established via joint ventures with Turkish Tofas and Oyak Groups and KARSAN started production under the license of Peugeot. From the late 1960s to the 1980s, the efforts of assemblers to develop their own supply base in the scarcity of local suppliers, together with the supportive policies of the import substitution strategy adopted by the governments of the time, helped the development of the domestic components industry in Bursa. Thanks to these dynamics, by the end of the 1970s, there emerged a small and medium enterprise-dominated network of suppliers in Bursa producing mainly for the domestic market.

Like many manufacturing nodes of the world, Bursa entered into a profound structural change after a gradual process of deregulation and trade liberalization following a political instability and economic crisis in 1978. Started with the export-oriented industrialization strategy adopted in 1980, and continued throughout the 1990s, quantitative restrictions were abolished, import of cars and parts was liberalized and import duties were lowered. Added to these were incentives and subsidies for foreign manufacturers investing in Turkey. Forced to compete with international competition, vehicle manufacturers put pressure on their suppliers increasing their requirements in relation to quality, delivery and flexibility. At the same time, the Customs Union agreement signed with the European Union in 1995 forced suppliers to adopt quality certification, standardization, measurement, accreditation, test and certification legislations of the EU over a period of 5 years. The adjustment efforts of suppliers continued in the following years but in the face of a number of crises as a result of which demand volatility and market uncertainty have become the characterizing features of the industry after $1990^{5}$ (Duruiz, 2004).

From a GVC perspective, the major implication of this adjustment process was that suppliers could link up with a diverse array of lead firms. First, the automotive sector witnessed a significant increase in foreign investments. While new assembly investments were realized in Turkey, there were also significant increases in the shares of existing car manufacturers. ${ }^{6}$ These new assembly investments encouraged new foreign investments in the components industry. In line with the global sourcing strategies of these assemblers, foreign component suppliers were either encouraged to take over the most successful suppliers or establish greenfield investments. ${ }^{7}$

Second, domestic suppliers opened up to export markets establishing ties to a variety of lead firms. By 2002, the share of the value of automotive exports of Bursa reached 
$1,559,759$ thousand US $\$, 45 \%$ of the value of Bursa's manufacturing exports (Undersecretariat of the Prime Ministry for Foreign Trade, 2007). In 2006, the value of Bursa's automotive exports more than doubled and reached 3,646,568 thousand US\$-more than 50\% of the value of its manufacturing exports (Undersecretariat of the Prime Ministry for Foreign Trade, 2007).

Third, thanks to the Customs Union, the EU has become the major trade partner of suppliers in Bursa and Turkey in automotives. From 1995 onwards, the share of the value of Turkish automotive exports to EU countries increased gradually. By 2000s, suppliers in Bursa and Turkey achieved full scale integration in the European regional automotive system. By the year 2003, 73\% of the 6.5 billion US\$ automotive exports of Turkey were oriented towards EU25 (KOSGEB, 2004).

At one level, the increasing role of global lead firms when coupled with Turkey's trade agreement with the EU has had significant impacts on the supply industry in Bursa. On the one hand, there has been a significant rise in process standards and product quality. On the other hand, the assemblers and their lead firms that entered the Turkish market developed models and product and process specifications, helped components manufacturers in the technology and organization of production and inspected the quality of their products and processes on site. Suppliers in Bursa concentrated on the production process, while the lead firms were responsible for product development and design. Gereffi (1999, p. 53) attributes this process to "organizational succession", which implies that the succession of lead firms permitted suppliers in Bursa to learn a great deal from global lead firms how to improve their production processes, attain quality standards and increase the speed of response as they met customer demands. In GVC terms, this implies that the lead firms employed captive modes of coordination in supplying components from manufacturers in Bursa. Since then, however, there have been new developments in the organization of automotive production. The global automotive industry is not what it was in the 1990s nor is the interaction between the lead firms and their suppliers in Bursa. The rest of the paper aims to unveil this transformation and focuses on the ways in which the governance of the automotive value chain in Bursa has evolved. To do so, it concentrates on the linkages lead firms have established with suppliers in Bursa and the ways in which they are coordinated.

\subsection{Integration of Suppliers in Bursa into the Automotive Value Chain}

Before directing attention to the ways in which the automotive value chain in Bursa is coordinated on the basis of the typology of governance suggested by Gereffi et al. (2005), I shall look at the different chains into which suppliers in Bursa are integrated. For this purpose, I classify value chains of component firms by ownership and the type of supply chain they established in the automotive value chain. First, in order to identify whether the value chain is established by a TNC-owned firm or not, I distinguish between firms which are subsidiaries of a global TNC, have share ownership with a global TNC and which are nationally owned. Secondly, I identify different types of supply chains on the basis of market orientation and position in the supply chain. Market orientation involves three categories of component firms: those which supply export markets only, which supply the national market only and which supply both export markets and the national market. The final category of diversified supply chains reflects the strategy of firms to diversify their chains and addresses the idea that firms most of the time are inserted in different chains (Lee \& Chen, 2000; Humphrey \& Schmitz, 2002a, 2002b; Bazan \& 
Table 4. Integration of Bursa in the automotive value chain: value chains by ownership and supply chains

\begin{tabular}{lcr}
\hline Type of value chain & Number of firms & Per cent \\
\hline Value chains by ownership & & \\
TNC subsidiaries' value chains & 8 & 7.8 \\
TNC share owners' value chains & 10 & 9.7 \\
Nationally owned firms' value chains & 85 & $\mathbf{8 2 . 5}$ \\
Supply chains & 28 & $\mathbf{2 7 . 2}$ \\
International supply chains & 29 & $\mathbf{2 8 . 2}$ \\
Diversified supply chains & 12 & 11.7 \\
National OEM's supply chains & 34 & $\mathbf{3 3 . 0}$ \\
Domestic supply chains & 103 & 100.0 \\
Total & &
\end{tabular}

Source: Survey data.

Navas-Aleman, 2004; Kishimoto, 2004). On the other hand, to provide a systematic analysis of firms in the hierarchy of the supply chain, I devote a closer look at component firms that supply the national market and provide a distinction between suppliers on the basis of their position in the national supply chain. A distinction is made between first-tier suppliers to original equipment manufacturers (OEMs) in the home country of the component firm and second- and lower-tier suppliers in the supply network of the home country of the component firm.

Table 4 provides information on the significant categories of chains produced by the responses in the database. The table first of all shows the significant share of nationally owned firms' chains (82.5\%) which reflects the historical strength of the domestic supply chain that developed in the 1970s, thanks to the efforts of assemblers to develop a supply base in Bursa and the supportive policies of the import-substitution strategy. In contrast, and despite the increasing drive towards foreign direct investment (FDI) after the 1990s as observed in the automotive producing countries in the global scale, the share of TNC-owned chains remains relatively lower $(18.75 \%)$. Of these, $7.8 \%$ are chains of the subsidiaries of a global TNC, while $9.7 \%$ are established by domestic firms which have share ownership with a global TNC. That the latter has a higher share indicates that the drive towards FDI in Bursa took place in the form of ownership links that built on prior contracting links between the most successful domestic component firms with the necessary industrial and managerial skill and Western partners, which over time developed into a joint venture relationship or ended up with the acquisition of a major stake in the former by the latter.

The table also shows different types of supply chains into which firms in Bursa are integrated. Accordingly, a significant share of components manufacturers in Bursa supplies export markets (55.4\%). Of these, $27.2 \%$ supply export markets only and $28.2 \%$ diversify their supply relations; that is, supply both export markets while at the same time supplying national OEMs (28.2\%). On the other hand, only $11.7 \%$ of the firms in Bursa supply national OEMs only, while a significant majority of components manufacturers operate as secondor lower-tier suppliers in the domestic supply network (33\%). Overall, these figures reveal that suppliers in Bursa are integrated in export chains and a significant majority of them are placed in the second or lower tier in the hierarchy of the automotive value chain. 


\subsection{Automotive Value Chain Governance in Bursa}

As discussed before, the GVC framework has put special emphasis on the governance of value chains recognizing the existence of asymmetries in GVCs due to the power of lead firms in controlling what is to be produced, how it is to be produced and how much will be produced. In this section, I shall direct attention to this issue and investigate the ways in which lead firms coordinate the chains into which suppliers in Bursa are integrated.

Table 5 illustrates the distribution of firms by the type of value chain governance and reveals important developments in relation to the governance of the automotive value chain in Bursa. Firstly, contrary to the initial expectation to find the type "exclusion" in the periphery of automotive production, ${ }^{4}$ the share of this outcome in Bursa is only $10.4 \%$. This implies that it has become a requirement for suppliers to acquire a minimum of certain competencies to become integrated in the global automotive value chain. Secondly, captive and market-based relations are rather limited in the automotive value chain in Bursa (19.8\% and 12.5\%, respectively). As mentioned earlier, as suppliers in the automotive industry have been increasingly given responsibility for design and product development, investing in supplier relationships to make it long term and more collaborative has become a requirement. Evidence from Bursa implies in this context that it has become increasingly difficult to maintain captive and market-based relations. On this issue, MacDuffie and Helper (2005) and Sturgeon et al. (2008) show that the traditional captive relations in Japanese production networks and market-based nature of relations in US production networks were forced to adjust to the requirement of investing in network-based relationships, driving supplier relations towards more relational form of governance.

However, as Table 5 indicates, relational modes of governance do not exist in Bursa. This finding may not be surprising when one recalls the assertion of the GVC framework that it is not a likely prospect for suppliers in developing country production nodes to develop relational chains with their customers since they most of the time lack the knowledge-based competencies required for such chains to develop (Humphrey \& Schmitz, 2004). Table 5 reveals however that modular production networks have become more extensive for lead firms as a way of sourcing components from suppliers in Bursa (57.3\%). This provides evidence to argue in the case of Bursa that network-based relationships with customers took the form of modular value chains characterized by working to the specifications of customers, sharing competencies and higher supplier capability in design and product development.

Table 5. Value chain governance in Bursa

\begin{tabular}{llcr}
\hline & Type of value chain governance & Frequency & Per cent \\
\hline Bursa & Modular & 55 & $\mathbf{5 7 . 3}$ \\
& Market & 12 & 12.5 \\
Captive & 19 & 19.8 \\
Relational & - & - \\
& Exclusion & 10 & 10.4 \\
& Total & 96 & 100.0 \\
\hline
\end{tabular}

Source: Survey data. 
This is an important finding as it has significant implications on the ways in which the governance of the automotive value chain in Bursa has evolved. As mentioned earlier, the automotive value chain in Bursa has seen a significant restructuring since the late 1980s when suppliers in Bursa opened up to export markets. This opening up meant that suppliers in Bursa established links with a diverse array of lead firms, which allowed them to find opportunities to learn a great deal from global lead firms how to improve their production processes, attain quality standards and increase the speed of response as they met customer demands. Evidence provided here indicates that since then suppliers in Bursa gained design and product development capabilities (cf. Evren, 2002) and that the Turkish automotive components cluster in Bursa now constitutes a modular value chain.

It is worth mentioning at this point that this development path pursued by suppliers in Bursa has been influenced and enabled by the changing strategies of lead firms in the context of the organizational restructuring of the automotive components industry. This inter alia involved the diffusion of design responsibility to suppliers. In the automotive industry, assemblers have been outsourcing their design and product development functions since the mid-1980s, and the development that direct suppliers to assemblers have been increasingly taking on design and product development responsibilities is nothing new. Recent evidence however suggests that first-tier suppliers in the automotive value chain started to face difficulties in overcoming the costs of mastering all the design, technology and manufacturing operations as well as managing time. They increasingly require their lower-tier suppliers to have design and product development expertise in order to optimize their learning processes, minimize costs and share the risks with lower-tier suppliers (Follis et al., 2002; Herrigel, 2004). The implication of this recent tendency on inter-firm relations is exemplified by Follis et al. (2002), Herrigel (2004) and Whitford and Enrietti (2005). The evidences they provide imply that changes in the assembler supplier relationships are moving down the supply chain, with relationships being intensified between first- and second-tier suppliers especially in technology and quality and increasing requests from the second- and lower-tier suppliers for design expertise.

These evidences altogether suggest that lead firms in the automotive industry are in a tendency to relinquish the design and product development functions. Obviously, this is a development that challenges the prevailing view in the literature that design and product development capabilities are likely to be typically controlled by global lead firms. Instead, it points to the potentials the organizational restructuring of the automotive components industry has offered to manufacturers in the periphery of automotive production. Evidence provided in this paper suggests that suppliers in Bursa have taken advantage of this opportunity to establish and upgrade a critical set of design and product development capabilities and change the form of interactions with their customers. This is an important finding as it points to the fragility of GVC governance and how this fragility opens up new opportunities for local producers in the periphery (Tokatli \& Kızılgün, 2004). By taking advantage of these opportunities, Turkish suppliers could upgrade their competencies and break out of the lock-in of captive chains, as a result of which their interactions with lead firms have taken a new form. In contrast to most of the research in the GVC framework which anticipated it an illusion for peripheral suppliers to break out of being locked into the unequal power relationships in GVCs of TNCs, the Bursa case highlights that value chain governance is dynamic and that there is room for peripheral producers to change power asymmetries in GVCs. 


\section{Concluding Remarks}

By using insights from the GVC perspective, this paper has accounted for the ways in which lead firms in the automotive industry coordinate their value chains with suppliers in the periphery of automotive production. To do so, it has provided a survey of the automotive value chain in a peripheral production node, Bursa, which has been integrated in the value chains of European and global lead firms after the 1990s. The organizational changes taking place in the automotive industry created significant opportunities for Turkish suppliers in the 1990s. The strategies of lead firms when coupled with the liberalization process the Turkish economy has experienced since the 1980s and the GATT agreement signed with the EU enabled Turkish suppliers to establish links with a variety of lead firms and become integrated in their global and European regional production networks. A significant outcome of this integration was that Turkish suppliers obtained and developed capabilities to improve production processes, attain quality standards and increase the speed of response. In this article, I have called attention to the fact that since then suppliers in Bursa's components industry increased their competencies also in design and product development. I have also argued that lead firms in the European and global automotive system are extensively employing modular value chains when sourcing components from these suppliers partly because of the increase in their competencies.

The Bursa case clearly indicates that despite all the structural requirements associated with a specific type of value chain governance, suppliers in peripheral places such as Turkey have some room for undertaking higher value-added competencies and breaking power asymmetries in value chains. As the competencies of suppliers increase, the need for lead firms to control their suppliers tends to be less and more even modes of coordination become more likely to develop. This implies that value chains are continuously constituted, transformed and reproduced through evolving power relations (Dicken et al., 2001; Smith, 2003; Tokatl1, 2007). Hence, our evidence from Bursa provides support for the theoretical position that governance structures in GVCs are not stable. Instead, local suppliers in the periphery may find ways to mitigate the asymmetric distribution of power between themselves and the lead firms and in fact may change the mode of GVC governance.

What is also important here is the extent to which lead firms are willing to relinquish some of their competencies. As I discussed, the organizational restructuring of the components industry included the diffusion of design and product development capabilities down the hierarchy of the supply chain. In other words, design and product development is less in the domain of direct suppliers to vehicle manufacturers basically because first-tier suppliers started to face difficulties in mastering all the design, technology and manufacturing operations and increasingly required their lower-tier suppliers to have design and product development expertise so that they optimize their learning processes, minimize costs and share the risks with lower-tier suppliers (Follis et al., 2002; Whitford \& Enrietti, 2005; Herrigel, 2004). Obviously, this is a development that challenges the prevailing view in the literature that design and product development capabilities are likely to be typically controlled by global lead firms. Evidence from Bursa indicates that suppliers in Bursa took advantage of this opportunity and managed to obtain the competencies that lead firms governing the automotive value chain in Bursa were willing to relinquish.

What policy implications do these findings have? Until recently, the key question for governments was how to develop policies that maximize the potential for domestic 
suppliers for insertion into value chains. In this respect, removal of restrictions and local content requirements to increase the export potential of suppliers has played an important role. Now that the majority of domestic suppliers in developing countries have been integrated into GVCs, new policies must be implemented which will maintain their integration. The strategy employed by suppliers in Bursa seems to be to build on value chain resources. They make components to be sold under the brand names of a number of customers, some of whom are willing to relinquish those functions. To do so, they built on opportunities offered by value chain leaders to develop capabilities sufficient to produce these components with quality and design features, through which they are more likely to command higher prices and raise the barriers to the entry of competitors. This implies that a viable strategy to maintain integration in value chains is to continuously increase the level of competencies. However, building on value chain resources alone may not be sufficient and may require aligning value chain resources with firm-level efforts and systems of innovation. This is especially important since recent evidence shows that the requirements of lead firms from their suppliers in value chains are ever more demanding, but the level of support they provide is increasingly decreasing (Quadros, 2002). This implies that there is a continuing need for firm-level strategic intent for investing in capability upgrading. Lee and Chen's (2000) research on capability development in the Taiwanese computer cluster showed that instead of passively waiting for knowledge to arrive through value chain linkages, they sort out the knowledge necessary for their competence-building efforts. Of course, this is a matter of having managerial and financial resources, and the majority of supplier firms in the periphery lack. However, large firms may play the leader role by taking the initiative and facilitating upgrading efforts within the cluster, since they are more likely to have such resources (Humphrey, 2003a).

Finally, such firm-level efforts need to be complemented by regional and national systems of innovation which will promote competence development. Systems of innovation help firms to establish strategic links with leading research and development institutions, universities and the like and provide firms with technical support, well-educated researchers and technical staff. Elements of systems of innovation-institutions, joint efforts, learning, etc.- - also help local firms to escape from being locked-in value chain relationships with a small number of major customers, the information and support coming from whom may be undermined by the emergence of new competitors in the long term (Schmitz, 1999; Humphrey, 2003a). It is when the firm-level efforts and systems of innovation are aligned with strategies of global lead firms in producer-driven value chains that peripheral production nodes are more likely to overcome the upgrading challenges they have to face in the global economy and maintain their competitive advantage in global chains.

\section{Acknowledgements}

This research paper is part of the $\mathrm{PhD}$ dissertation completed at the University of Sussex, part of which was funded by the EU Commission in Framework Programme 6, Priority 7 on "Citizens and Governance in a Knowledge-based Society", contract no. CIT5-028519. I would like to express my thanks to Prof. Mick Dunford for his supervision, academic advice, guidance and support throughout my research. I would also like to thank Prof. John Humphrey and Prof. Ayda Eraydın for their valuable comments on the dissertation, most of which are incorporated in this paper. Finally, I thank the anonymous referees for 
their valuable comments on earlier versions of the paper. None of these people is responsible for what is or is not said.

\section{Notes}

1. Modules are a group of components, which are designed to be relatively independent of one another by defining standardized set of interfaces, but are functionally integrated as parts of a larger system (Baldwin \& Clark, 2000). A system is a group of modules that operate together to provide a specific function (Dicken, 2003).

2. It should be noted however that the integral nature of product architecture in vehicles puts limits on switching suppliers. This is because of the necessity of ensuring compatibility of components and subsystems in order to make them work well as a product when put together (Langlois \& Robertson, 1992; Sako, 2002; Herrigel, 2004).

3. Gereffi et al. (2005, p. 101) underline that "A high priority for the future will be the development of methods for measuring the key variables in the model [they suggested]. Effective proxies for transactional complexity, level of codification, and supplier competence must be identified and tested in the field". This paper is one of the rare attempts to do so (for another see Pietrobelli \& Saliola, 2008).

4. Of the eight outcomes, Gereffi et al. (2005) treat the first five as modes of governance. In GVC terms, hierarchical chains reflect intra-firm trade between a TNC and its subsidiaries. This article treats each semi-independent subsidiary as an independent profit centre (Dunford, 2009) and looks at the interfirm relations of subsidiaries with their customers. This requires that the type "hierarchy" is discarded. The type named "exclusion" here represents the situation when firms are likely to be excluded from the value chain due to their low capabilities despite low complexity of the transaction and high ability to codify the transaction. Gereffi et al. (2005) recognize the importance of this outcome but do not consider it as a governance type on its own. Assuming that it may be a widespread outcome in the periphery of automotive production, this paper treats it as a type. The "unlikely" outcomes represent combinations of low complexity of transactions and low ability to codify. These outcomes are excluded in further investigation with the assumption that the questionnaires were not successful (seven firms). In the final situation, a number of 96 supplier firms are distributed among five types of value chain governance.

5. First, the economic crisis in 1994 had serious impacts on the metropolitan areas of Turkey, including Bursa, causing sharp declines in domestic demand. Second, the negative impacts of the East Asian crisis in 1998 were reinforced by a major earthquake in the region that locates Bursa where a significant part of manufacturing industry, including the automotive, was located. Third, the IMF-backed stabilization programme that was initiated following the 1998 crisis came to an end which was followed by political instability and a financial crisis in 2001.

6. Of the 17 vehicle assemblers in Turkey, 8 of them have seen an increase in the share of foreign capital by 2007.

7. The number of foreign components suppliers in Turkey increased from 138 in 1999 (Istanbul Sanayi Odas1, 2002) to 163 in 2005 (Undersecretariat of the Prime Ministry for Foreign Trade, 2005), of which $55(34 \%)$ of them were located in Istanbul, 44 (27\%) in Bursa and 15 (9\%) in Kocaeli.

\section{References}

Baldwin, C. \& Clark, K. (2000) Design Rules (Cambridge, MA: MIT Press).

Barnes, J. \& Kaplinsky, R. (2000) Globalisation and trade policy reform: Whither the automobile components sector in South Africa?, Competition and Change, 4(2), pp. 211-243.

Barnes, J., Kaplinsky, R. \& Morris, M. (2004) Industrial policy in developing economies: Developing dynamic comparative advantage in the South African automobile sector, Competition and Change, 8(2), pp. 153-172.

Bazan, L. \& Navas-Aleman, L. (2004) The underground revolution in the Sinos Valley-A comparison of upgrading in global and national value chains, in: H. Schmitz (Ed.) Local Enterprises in the Global Economy: Issues of Governance and Upgrading, pp. 110-139 (Cheltenham: Edward Elgar).

Camuffo, A. (2002) Rolling out a "world car": Globalisation, outsourcing and modularity in the Auto Industry. Available at imvp.mit.edu/papers/0001/camuffo1.pdf (accessed 19 March 2007). 
Dicken, P. (2003) Global production networks in Europe and East Asia: The automobile components industries, Global Production Networks (GPN) Working Paper, No. 7, The University of Manchester, Available at http://www.sed.manchester.ac.uk/geography/research/gpn/gpnwp7.pdf (accessed 12 January 2006).

Dicken, P., Kelly, P. F., Olds, K. \& Yeung, H. W.-C. (2001) Chains and networks, territories and scales: Towards a relational framework for analysing the global economy, Global Networks, 1(2), pp. 89-112.

Dolan, C. \& Humphrey, J. (2000) Governance and trade in fresh vegetables: The impact of UK supermarkets on the African horticulture industry, Journal of Development Studies, 37(2), pp. 147-176.

Dunford, M. (2009) Globalization failures in a neo-liberal world: The case of Fiat Auto in the 1990s, Geoforum, 40(2), pp. 145-157.

Duruiz, L. (2004) Challenges for the Turkish car industry on its way to the integration with European Union, in: J. Carillo, Y. Lung \& R. Van Tulder (Eds) Cars, Carriers of Regionalism, pp. 91-103 (Basingstoke: Palgrave Macmillan).

Evren, Y. (2002) Supply networks in the car industry. Do peripheral economies perform specific tasks? Lessons from the Turkish car industry, International Planning Studies, 7(4), pp. 283-302.

Follis, M., Enrietti, A. \& Whitford, J. (2002) Improving performances at the second tier of the automotive supply chain: Fiat's "guided improvement" programme in comparative perspective, Tenth Gerpisa International Colloquium, Paris, France, 6-8 June. Available at http://www.gerpisa.univ-evry.fr/rencontre/10. rencontre/AFollis.pdf (accessed 28 June 2007).

Gereffi, G. (1999) International trade and industrial upgrading in the apparel commodity chain, Journal of International Economics, 48(1), pp. 37-70.

Gereffi, G. (2001) Shifting governance structures in global commodity chains. With special reference to the internet, American Behavioral Scientist, 44(10), pp. 1616-1637.

Gereffi, G., Humphrey, J. \& Sturgeon, T. (2005) The governance of global value chains, Review of International Political Economy, 12(1), pp. 78-104.

Herrigel, G. (2004) Emerging strategies and forms of governance in high-wage component manufacturing regions, Industry and Innovation, 11(2), pp. 45-79.

Humphrey, J. (2000) Assembler-supplier relations in the auto industry: Globalisation and national development, Competition and Change, 4(3), pp. 245-271.

Humphrey, J. (2003a) Opportunities for SMEs in developing countries to upgrade in a global economy, Small Enterprise Development (SEED) Working Paper, No. 43, Geneva: International Labour Organisation. Available at http://www.ilo.org/empent/Whatwedo/Publications/lang-en/docName-WCMS_117688/index. htm (accessed 10 December 2005).

Humphrey, J. (2003b) Globalization and supply chain networks: The auto-industry in Brazil and India, Global Networks, 3(2), pp. 121-141.

Humphrey, J. \& Memedovic, O. (2003) The global automotive industry value chain: What prospects for upgrading by developing countries, UNIDO Sectoral Studies Series, Vienna.

Humphrey, J. \& Schmitz, H. (2000) Governance and upgrading: Linking industrial cluster and global value chain research, IDS Working Paper, No. 120.

Humphrey, J. \& Schmitz, H. (2002a) How does insertion in global value chains affect upgrading in industrial clusters? Regional Studies, 36(9), pp. 1017-1027.

Humphrey, J. \& Schmitz, H. (2002b) Developing Country Firms in the World Economy: Governance and Upgrading in Global Value Chains, INEF Report No. 61, Duisburg: University of Duisburg. Available at http://www.ids.ac.uk/ids/global/vwpap.html (accessed 28 September 2006).

Humphrey, J. \& Schmitz, H. (2004) Chain governance and upgrading: Taking stock, in: H. Schmitz (Ed.) Local Enterprises in the Global Economy: Issues of Governance and Upgrading, pp. 349-381 (Cheltenham: Edwards Elgar).

Istanbul Sanayi Odası (2002) Otomotiv Sanayii Sektörü, Yayın No. 2002/4 (Istanbul: Cem Ofset Matbaacılık).

Kishimoto, C. (2004) Clustering and upgrading in global value chains: The Taiwanese personal computer industry, in: H. Schmitz (Ed.) Local Enterprises in the Global Economy: Issues of Governance and Upgrading, pp. 233-264 (Cheltenham: Edwards Elgar).

KOSGEB (2004) Türk Otomotiv Sanayi’ne Bakış, Ekonomik ve Stratejik Araştırmalar Merkez Müdürlügüü, Ankara.

Langlois, R. N. \& Robertson, P. L. (1992) Networks and innovation in a modular system: Lessons from the microcomputer and stereo component industries, Research Policy, 21(4), pp. 297-313.

Layan, J. (2000) The integration of peripheral markets: A comparison of Spain and Mexico, in: J. Humphrey, Y. Lecler \& M. S. Salerno (Eds) Global Strategies and Local Realities: The Auto Industry in Emerging 
Markets, pp. 122-148 (Paris: GB: MacMillan Press). Available at http://www.univ-evry.fr/labos/gerpisa/ actes/31/31-5.pdf (accessed 28 September 2006).

Lee, J.-R. \& Chen, J.-S. (2000) Dynamic synergy creation with multiple business activities: Toward a competence-based growth model for contract manufacturers, in: R. Sanchezz \& A. Heene (Eds) Theory Development for Competence-Based Management, Advances in Applied Business Strategy, pp. 209-228 (Stanford, CT: JAI Press).

MacDuffie, J. P. \& Helper, S. (2005) Collaboration in supply chains: With and without trust, in: C. Heckscher \& P. S. Adler (Eds) The Firm as a Collaborative Community: The Reconstruction of Trust in the Knowledge Economy, pp. 417-466 (New York: Oxford University Press).

Pietrobelli, C. \& Saliola, F. (2008) Power relationships along the value chain: Multinational firms, global buyers and performance of local suppliers, Cambridge Journal of Economics, 32(6), pp. 947-962.

Posthuma, A. C. (2005) Industrial renewal and inter-firm relations in the supply chain of the Brazilian automotive industry, Series on upgrading in small enterprise clusters and global value chains, ILO. Available at http:// www.ilo.org/wcmsp5/groups/public/—ed_emp/—emp_ent/—ifp_seed/documents/publication/wcms_ 117685.pdf (accessed 25 May 2006).

Quadros, R. (2002) Global quality standards, chain governance and the technological upgrading of Brazilian autocomponent producers, IDS Working Paper, No. 156, Institute of Development Studies, Brighton.

Sadler, D. (1998) Changing inter-firm relations in the European automotive industry: Dependence or enhanced autonomy for components producers? European Urban and Regional Studies, 5(4), pp. 317-328.

Sako, M. (2002) Modularity and outsourcing: The nature of co-evolution of product architecture and organisation architecture in the global automotive industry. 11th GERPISA International Colloquium, Paris, France, 11-13 June. Available at http://www.gerpisa.univ-evry.fr/rencontre/11.rencontre/papers/Sako.pdf (accessed 19 March 2007).

Schmitz, H. (1999) Global competition and local cooperation: Success and failure in the Sinos Valley, Brazil, World Development, 27(9), pp. 1627-1650.

Schmitz, H. (2004) Globalized localities: Introduction, in: H. Schmitz (Ed.) Local Enterprises in the Global Economy: Issues of Governance and Upgrading, pp. 1-19 (Cheltenham: Edwards Elgar).

Smith, A. (2003) Power relations, industrial clusters, and regional transformations: Pan-European integration and outward processing in the Slovak clothing industry, Economic Geography, 79(1), pp. 17-40.

Sturgeon, T. J. (2002) Modular production networks: A new American model of industrial organisation, Industrial and Corporate Change, 11(3), pp. 451-496.

Sturgeon, T. J. (2003) What really goes on in Silicon Valley? Spatial clustering and dispersal in modular production networks, Journal of Economic Geography, 3(2), pp. 199-225.

Sturgeon, T. J. \& Florida, R. (2000) Globalisation and jobs in the automotive industry, IPC Working Paper, No. 01-003, MIT, Industrial Performance Centre, Cambridge, MA.

Sturgeon, T. J. \& Lester, R. K. (2004) The new global supply-base: Challenges for local suppliers in East Asia, in: S. Yusuf, A. Altaf \& K. Nabeshima (Eds) Global Production Networking and Technological Change in East Asia, pp. 35-87 (New York, NY: Oxford University Press).

Sturgeon, T., van Biesebroeck, J. \& Gereffi, G. (2008) Value chains, networks and clusters: Reframing the global automotive industry, Journal of Economic Geography, 8(3), pp. 297-321.

Tokatl, N. (2007) Networks, firms and upgrading within the blue-jeans industry: Evidence from Turkey, Global Networks, 7(1), pp. 51-68.

Tokatli, N. \& Kizılgün, O. (2004) Upgrading in the global clothing industry: Mavi Jeans and the transformation of a Turkish firm from full-package to brand-name manufacturing and retailing, Economic Geography, 80(3), pp. 221-240.

Undersecretariat of the Prime Ministry for Foreign Trade (2005) Sektörler İtibariyle Üretim-Dış Ticaret İliskisi ve Rekabet Koşulları. Available at http://www.dtm.gov.tr (accessed 9 July 2007).

Undersecretariat of the Prime Ministry for Foreign Trade (2007) Available at http://www.dtm.gov.tr (accessed 9 July 2007).

Whitford, J. \& Enrietti, A. (2005) Surviving the fall of a king: The regional institutional implications of crisis at Fiat Auto, International Journal of Urban and Regional Research, 29(4), pp. 771-795.

Yusuf, S. (2004) Competitiveness through technological advances under global production networking, in: S. Yusuf, A. Altaf \& K. Nabeshima (Eds) Global Production Networking and Technological Change in East Asia, pp. 1-34 (New York, NY: Oxford University Press). 